\title{
MAGE-3 And -4 Genes as Possible Markers for Early Detection of Metastases in HCV Egyptian Patients Complicated By HCC
}

\author{
Yousri M Hussein ${ }^{1}$, Amal F Gharib ${ }^{1}$, Randa H Mohamed ${ }^{1}$, \\ Mohamed I Radwan ${ }^{3}$, Wael H Elsawy ${ }^{2}$ \\ ${ }^{1}$ Medical biochemistry, ${ }^{2}$ Clinical oncology and Nuclear Medicine and \\ ${ }^{3}$ Tropical Medicine Departments, Faculty of Medicine, \\ Zagazig University
}

\begin{abstract}
The dissemination of hepatocellular carcinoma (HCC) cells into the circulation plays a critical role in postoperative recurrence and metastasis. Early detection of metastatic tumor cells is critical to identify HCC patients at high risk of relapse. MAGE-3 and -4 genes were evaluated by reverse transcription polymerase chain reaction for the possibility of using them as new markers for early detection of metastases in $160 \mathrm{HCV}$ Egyptian patients, 115 of them were complicated with HCC. The expression of MAGE-3 and MAGE-4 mRNA in peripheral blood of patients with metastatic HCC, were $36 \%$ and 52\%, respectively. While the expression of MAGE-3 and MAGE-4 mRNA in peripheral blood of patients with localized HCC, were $12 \%$ and $16 \%$, respectively. Moreover at least one type of MAGE-3 or MAGE-4 mRNA was found in the peripheral blood of $68 \%$ of the metastatic HCC patients and in $20 \%$ of the localized HCC patients. While neither the controls nor the cirrhotic patients show expression of MAGE-4 mRNA in their peripheral blood. MAGE-3 and MAGE-4 may be a promising diagnostic tool for monitoring the prognosis of HCC patients and early detection of occult hematogenous metastasis of HCC.
\end{abstract}

\section{INTRODUCTION}

Hepatocellular carcinoma (HCC) is one of the most prevalent malignancies. Though regular abdominal ultrasonography (US) examination and serum alphafetoprotein (AFP) can detect small HCC at an early stage and there are many modalities of treatment, the recurrence and metastasis are frequent and the prognosis remains unsatisfactory. The high recurrence rate is probably attributed to the dissemination of HCC cells into blood circulation and that they proliferate in an immunosuppressive environment during and before therapy. The dissemination of HCC cells into the circulation plays a critical role in postoperative recurrence and metastasis $^{(1)}$.

Hepatocellular carcinoma (HCC) accounts for $80 \%$ of all primary liver cancers and ranks globally as the fourth leading cause of cancer-related death. Partial hepatectomy remains the best treatment option for selected patients with HCC without cirrhosis. Liver transplantation is well 
established as the gold standard for patients with HCC and cirrhosis in the absence of extrahepatic spread and macro-vascular invasion. Local regional therapy is indicated in selected patients who are not surgical candidates $^{(2)}$.

Early detection of metastatic tumor cells is critical to identify HCC patients at high risk of relapse and for the prescriptive therapy. However, it is difficult to detect such dissemination of HCC cells through blood route with conventional techniques $^{(3)}$.

With respect to HCC, although the serum level of AFP is a good biomarker for $\mathrm{HCC}$, it does not specifically reflect metastasis from HCC; previously both albumin and AFP mRNA are widely used as tumor markers for HCC cells in circulation. However, the reliability of using them as tumor markers have been challenged because both albumin and AFP mRNA are abundantly expressed in normal liver cells, they are released in the peripheral blood by either surgical injury of the liver or by diseases other than $\mathrm{HCC}$ such as hepatitis virus infection $^{(4)}$.

The MAGE g4ene family encodes tumor-specific antigens recognized by autologous cytotoxic $\mathrm{T}$ lymphocytes ${ }^{(5)}$ and composed of more than 25 genes in humans and are classified as type I MAGE genes (including MAGE-A, MAGE-B, and MAGE-C genes) and type II MAGE genes, which include those that reside outside the MAGE-A, MAGE-B, and MAGE-C genomic clusters ${ }^{(6)}$. The MAGE-A subfamily comprises 12 genes (MAGE-A1 to MAGE-A12), and is expressed in various types of tumors, but not in normal adult tissues, except for testis and placenta. The MAGE-A antigens are of particular interest for antitumor immunotherapy because they are strictly tumor specific and are shared by many tumors. Despite the isolation of growing numbers of MAGE genes, their function in normal tissues remains mostly unknown ${ }^{(7)}$.

MAGE-3 belongs to MAGE-A gene family, and is expressed in a significant proportion of tumors of various histological malignancies, and is silent in normal somatic cells except male germ line cells ${ }^{(\mathbf{8})}$. MAGE3 protein also exists in cytoplasm showing homogeneous, focal or scattered pattern of expression, and the expression undergoes a substantial change in distribution with increase in tumor size and invasiveness ${ }^{(9)}$.

How to discriminate well differentiated HCCs from noncancerou9s lesions, and how to suppress the recurrences that frequently occur after treatment are problems which should be solved. Detection of MAGE transcripts in peripheral blood mononuclear cells (PBMC) may be helpful in detecting circulating tumor cells which also may help in the early prediction of the relapse and prognosis of the $\mathrm{HCC}$ patients.

In the present study, we have carried out the reverse transcription polymerase chain reaction (RT-PCR) for MAGE-3 and -4 genes to evaluate the possibility of using these genes as new markers for early detection of metastases in hepatitis $\mathrm{C}$ virus (HCV) infected Egyptian patients complicated by HCC. 


\section{SUBJECTS \& METHODS}

We studied 165 Egyptian patients with $\mathrm{HCV}$ (50 patients with $\mathrm{HCV}$ complicated with cirrhosis, 40 patients with localized HCC and 75 patients with metastatic HCC)

The 50 patient presented by post chronic HCV hepatitis cirrhosis where selected according to the clinical and laboratory examination (18 child B \& 32 child $\mathrm{C}$ according to child-pugh classification). Hepatic malignancies in those patients were excluded by both abdominal US and AFP.

The $40 \mathrm{HCV}$ patients who presented by localized HCC were selected by abdominal US, all patients with single focal lesions with typical features of HCC, the HCC confirmed by Triphasic computed tomography (CT) and AFP. Fine needle aspiration biopsy (FNAB) was done in selected cases (focal lesion $<2 \mathrm{~cm}$ with normal AFP). Patients with multiple focal lesion and/or portal vein thrombosis were excluded. Distant metastases had been excluded by chest and abdominal $\mathrm{CT}$, isotopic bone scan and brain $\mathrm{CT}$ if there is a neurological manifestation.

Patients with $\mathrm{HCC}$ with distant and /or macro-vascular metastasis $(n=75)$ were selected from patients who presented by metastases during selection of the previous group.

75 healthy control Egyptian subjects age- and sex-matched with the patients, were randomly recruited.

\section{Biochemical measurements}

Blood samples were drawn from all subjects after an overnight fast. Sera were separated immediately and stored at $-20^{\circ} \mathrm{C}$.
Alanine aminotransferase (ALT), aspartate aminotransferase (AST), Albumin, urea and creatinine were measured in serum by routine enzymatic methods (spinreact), serum AFP concentration was measured by ELISA (kit provided by Biosource Europe S.A, Belgium), HCV antibodies by ELISA.

\section{RNA Extraction}

Total RNA was extracted using the protocol provided by the manufacturer. The cDNA was reverse transcribed in a $10 \quad \mu l$ mixture containing $6 \mu \mathrm{l}$ of total RNA , $0.5 \mu \mathrm{l}$ random primers (Promega, Madison, WI), $2 \mu \mathrm{l}$ of $5 \times$ reverse-transcriptase buffer (Life Technology, Gaithersburg, MD), $\quad 1 \quad \mu l \quad$ of dexoyribonucleoside triphosphate (dNTP) mixtures $(10 \mathrm{Mm}), 0.5 \mu \mathrm{l}$ of AMV reverse transcriptase $(5 \mathrm{U} / \mu \mathrm{l})$. The mixture was incubated at $37^{\circ} \mathrm{C}$ for $10 \mathrm{~min}, 52^{\circ} \mathrm{C}$ for $45 \mathrm{~min}, 95^{\circ} \mathrm{C}$ for $5 \mathrm{~min}$ and ice path for $5 \mathrm{~min}$.

\section{RT-PCR and Electrophoresis}

Detection of MAGE-3 and MAGE-4 genes were done according to ( 10$)$. The amplification reaction $(50 \mathrm{ml})$ contained $2.5 \mu \mathrm{l} \mathrm{cDNA}, 0.5 \mu \mathrm{l}$ each of $5 \mu \mathrm{M}$ primers, $0.5 \mu \mathrm{l}$ of Taq polymerase (GIBCO BRL), $0.5 \mu \mathrm{l}$ of dexoyribonucleoside triphosphate (dNTP) mixtures $(10 \mathrm{Mm})$ in buffer solution. The sequences of primers for PCR amplification were as follows:

MAGE-3; sense, 5TGGAGGACCAGAGGCCCCC-3, and antisense, 5GGACGATTATCAGGAGGCCTGC $-3$

MAGE-4; sense, 5ACCAAGGAGAAGATCTGCCAGT GGGTCTC-3, and antisense, 5- 
GTCGCCCTCCATTGCATTGTGC3

PCR was performed at $96^{\circ} \mathrm{C}$ for 5 minute followed by 35 cycles of $94^{\circ} \mathrm{C}$ for $1 \mathrm{~min}, 68^{\circ} \mathrm{C}$ for $2 \mathrm{~min}$ and $72^{\circ} \mathrm{C}$ for $4 \mathrm{~min}$, this was followed by 15 min of final extension at $72^{\circ} \mathrm{C}$ for MAGE-3, and $94^{\circ} \mathrm{C}$ for $30 \mathrm{sec}, 58^{\circ} \mathrm{C}$ for $30 \mathrm{sec}$ and $74^{\circ} \mathrm{C}$ for $30 \mathrm{sec}$, this was followed by $15 \mathrm{~min}$ of final extension for MAGE-4

Reverse- transcription RT- PCR for $\beta$-actin was done for each sample to ensure no degradation of RNA. Using forward primer-5'-GGC ATC GTG ATG GAC TCC G-3' and reverse-5'-GCT GGA AGG TGG ACA GCG A-3', PCR was performed at $96^{\circ} \mathrm{C}$ for 5 minute followed by 28 cycles of $94^{\circ} \mathrm{C}$ for $45 \mathrm{sec}, 55^{\circ} \mathrm{C}$ for 45 $\mathrm{sec}$ and $72^{\circ} \mathrm{C}$ for $45 \mathrm{sec}$.
The PCR products are separated in $2 \%$ agarose gel and visualized with ethidium bromide staining. The expected sizes of PCR products are $725 \mathrm{bp}$ for MAGE-3, $726 \mathrm{bp}$ for MAGE-4, and 613 bp for $\beta$-actin.

Statistical analysis

The results for continuous variables are expressed as means \pm SD. The means of the three genotype groups were compared in a one-way analysis of variance. The statistical significances of differences in frequencies of variants between the groups were tested using the chisquare $\left(\mathrm{x}^{2}\right)$ test. A difference was considered significant at $\mathrm{P}<0.05$. All data were evaluated using SPSS version 10.0 for windows.

\section{RESULTS}

Table 1. Characteristic of the studied group

\begin{tabular}{l|llll}
\hline & $\begin{array}{l}\text { Control } \\
\text { Group } \\
(\boldsymbol{n}=75)\end{array}$ & $\begin{array}{l}\text { Cirrhosis } \\
\text { Group } \\
(\mathbf{n}=50)\end{array}$ & $\begin{array}{l}\text { Localized } \\
\text { HCC group } \\
(\mathbf{n}=40)\end{array}$ & $\begin{array}{l}\text { Metastatic HCC } \\
\text { group (n=75) }\end{array}$ \\
\hline Age & $51.6 \pm 7.5$ & $50.7 \pm 5.5$ & $54.2 \pm 6.5$ & $56.3 \pm 8.1$ \\
ALT & $27.2 \pm 1.9$ & $64.2 \pm 30.8^{*}$ & $63.2 \pm 30.8^{*}$ & $59.2 \pm 19.2^{*}$ \\
AST & $23.4 \pm 6.8$ & $64.5 \pm 36^{*}$ & $62.5 \pm 36^{*}$ & $82.3 \pm 34.3^{*}$ \\
AFP $(\mathrm{ng} / \mathrm{ml})$ & $3.2 \pm 1.2$ & $127.5 \pm 40^{*}$ & $151.5 \pm 70^{*}$ & $671 \pm 328.4^{*}$ \\
\hline
\end{tabular}

* Significant difference from control group, $\S$ significant difference from cirrhosis group

Table 2. mRNA expression of MAGE-3 and -4 genes in all studied groups

\begin{tabular}{l|llll}
\hline & $\begin{array}{l}\text { Control } \\
\text { Group } \\
(\mathbf{n}=75)\end{array}$ & $\begin{array}{l}\text { Cirrhosis } \\
\text { Group } \\
(\boldsymbol{n}=50)\end{array}$ & $\begin{array}{l}\text { Localized } \\
\text { HCC group } \\
(\mathbf{n}=40)\end{array}$ & $\begin{array}{l}\text { Metastatic HCC } \\
\text { group }(\boldsymbol{n}=75)\end{array}$ \\
\hline MAGE3 + & 0 & 0 & $3(12 \%)^{*}$ & $27(36 \%)^{*}{ }^{*}$ \\
MAGE4+ & 0 & 0 & $4(16 \%)^{*}$ & $39(52 \%)^{*}$ \\
Combined + & 0 & 0 & $5(20 \%)^{*}$ & $51(68 \%)^{*}$ \\
\hline
\end{tabular}

* Significant difference from control group, $\S$ significant difference from localized HCC group 
Expression of MAGE-3 and MAGE-4

MAGE-3 and MAGE-4 mRNAs were positively expressed in peripheral blood of localized $\mathrm{HCC}$ patients $12 \%(3 / 25)$ and $16 \%(4 / 25)$ respectively; moreover when combining the expression of MAGE-3 and MAGE-4 mRNAs in the peripheral blood of patients with localized HCC, the rate of expression was $20 \%(5 / 25)$.

MAGE-3 and MAGE-4 mRNAs were positively expressed in peripheral blood of metastatic $\mathrm{HCC}$ patients 36\% (27/75) and 52\% (39/75) respectively; moreover when combining the expression of MAGE-3 and MAGE-4 mRNAs in the peripheral blood of patients with metastatic $\mathrm{HCC}$, the rate of expression were $68 \%(51 / 75)$. On the contrary none of the healthy subjects and cirrhotic patients showed expression of MAGE-3 and MAGE-4 mRNAs in their peripheral blood

\section{DISCUSSION}

The early dissemination of malignant cells to secondary sites is the main cause of mortality of patients with malignant solid tumors. Metastatic spread through vessels is the most important factor affecting the prognosis of $\mathrm{HCC}$ patients. If the metastatic HCC cells via hematogenous route can be sensitively and specifically determined at early stage, more beneficial therapeutic methods could be manipulated ${ }^{(11)}$.

Conventional diagnostic procedures usually fail to detect circulating tumor cells, while reverse transcriptase-polymerase chain reaction (RT-PCR) amplification of specific DNA sequences using synthesized oligonucleotide primers that flank the target DNA fragment of interest is increasingly applied in the detection of micrometastasis of cancer cells ${ }^{(\mathbf{1 1})}$. Reverse transcriptasepolymerase chain reaction (RT-PCR) amplification of genes expressed by the tumor in a tissue-specific manner is the method with the highest diagnostic sensitivity allowing the identification of one tumor cell in up to $10^{7}$ normal cells in various sources such as blood, bone marrow, lymph nodes, urine or stool ${ }^{(12 \& 13)}$.

Detection of micrometastasis in $\mathrm{HCC}$ is still a controversial issue. As the two frequently used mRNA markers in detection of HCC, albumin and mRNA AFP are also shown to be expressed in blood of patients with hepatitis, liver cirrhosis and the liver infectious diseases such as $\mathrm{HBV} / \mathrm{HCV}$ infection $^{(\mathbf{1 4})}$. Furthermore, AFP transcripts was detected even in the blood samples from patients without HCC after the surgical injury of the liver, which results in the shedding of liver cells into circulation under surgical operation ${ }^{(\mathbf{1 5})}$. Thus, AFP represents an indicator of ongoing liver damage without absolute specificity for hepatocellular carcinoma (Peck-Radosavljevic et al., 19981 (16,17\&18).

MAGE gene transcripts have been regarded as tumor-specific markers and were found to be highly expressed in variety of histological types of cancers ${ }^{(3)}$. When overexpressed in the cytosol of cancer cells, MAGE proteins are proteolytically processed, transported to the endoplasmic reticulum, and 
then presented on the cell surface as antigenic major histocompatibility complex-associated peptides ${ }^{(6)}$. Thus, attention has been focused on the potential of MAGE as a target for cancer immunotherapy.

The MAGE-3 and MAGE-4 genes are members of the CT (cancer/testis) antigen family used as cancer specific markers. It has been reported that MAGE-3 and MAGE-4 mRNAs are positive in HCC tissue, but there is no MAGE expression in pericancerous tissue, hepatitis,

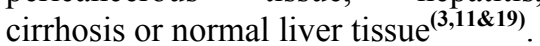

Our goal is to detect occult hematogenous metastasis of $\mathrm{HCC}$ cells by RT - PCR of MAGE-3 and/or MAGE-4 transcripts and to combine these markers with each other to detect HCC cells in the peripheral blood in order to elevate their sensitivity and specificity.

The important implication for the detection of occult hematogenous metastasis of HCC cells by RT - PCR of MAGE-3 and/or MAGE-4 transcripts, is its value in the prediction of recurrence after treatment and prognosis of the disease.

In our study, the expression of MAGE-3 and MAGE-4 mRNA in peripheral blood of patients with metastatic HCC, were $36 \%$ and $52 \%$, respectively. While the expression of MAGE-3 and MAGE-4 mRNA in peripheral blood of patients with localized HCC, were $12 \%$ and $16 \%$, respectively. This is in accordance with $^{(3)}$ who reported that MAGE-3 was expressed in $33.3 \%$ in peripheral blood of HCC patients and 53.3\% in HCC tissues while Zhang et al. $(2008)^{\mathbf{( 2 0 )}}$ reported that MAGE-3 was expressed in $20.1 \%$ in peripheral blood of HCC patients and $60.5 \%$ in HCC tissues.

Up to our knowledge our study is the first study to detect MAGE-4 mRNA expression in peripheral blood of patients with HCC. MAGE-4 mRNA was expressed in peripheral blood of $52 \%$ of patients with HCC, while neither the controls nor the cirrhotic patients show expression of MAGE-4 mRNA in their peripheral blood. Previous studies about MAGE4 and HCC is minimal. (11) reported that MAGE-4 mRNA was expressed in $18 \%$ HCC tissues while ${ }^{(21)}$ found that MAGE-4 protein was not only significantly increased in $\mathrm{HCC}$, but also in HCV-related cirrhotic liver patients and these cirrhotic patients are already at high risk to develop HCC.

At least one type of mRNA was found in the peripheral blood of $68 \%$ of the metastatic HCC patients, which is markedly higher than the $36 \%$ and $52 \%$ of the patients who were positive only by MAGE-3 or MAGE-4 mRNA detection, we also found at least one type of mRNA was found in the peripheral blood of $20 \%$ of localized HCC patients, which is markedly higher than the $12 \%$ and $16 \%$ of the patients who were positive only by MAGE-3 or MAGE-4 mRNA detection. So combining detection of MAGE-3 and MAGE-4 mRNAs in PBMCs is a feasible method as this method possesses high sensitivity and specificity, and is practical in detecting tumor cells in the blood.

Interestingly our results showed that the positive rate of expression MAGE-3 and MAGE-4 mRNA is markedly increased in peripheral 
blood of metastatic HCC patients than in peripheral blood of localized HCC patients, while patients with hepatitis, cirrhosis or the 75 healthy subjects showed no expression of MAGE-3 or MAGE-4 mRNA so using MAGE-3 or MAGE-4 mRNA expression in peripheral blood of in patients with localized HCC may be helpful in early detection of circulating cancer cells and consequently early identification of distant metastasis. As blood dissemination is the main metastatic route for $\mathrm{HCC}^{(\mathbf{2 2})}$, identifying and dynamically monitoring blood cancer cells may be helpful in estimating prognosis of $\mathrm{HCC}$, guiding treatment and avoiding recurrence since if a small number of cancer cells enter the blood circulation before surgery, relapse may occur after surgery even though the HCC is of a small size ${ }^{(23)}$

\section{Conclusion}

A cancer specific multi-marker assay such as MAGE-3 and MAGE-4 may be a promising diagnostic tool for monitoring $\mathrm{HCC}$ in $\mathrm{HCV}$ infected Egyptian patients and early detection of occult hematogenous metastasis of HCC with better sensitivity and specificity and this may be valuable in the prediction of the prognosis of the disease and construction of the guidelines for treatment.

\section{Acknowledgments}

This study was funded with the support of academic research in Zagazig University Projects, Zagazig University. Postgraduate \& Research Affairs.

\section{REFRENCES}

1. Sakon M, Nagano H, Nakamori S, Dono K, Umeshita K,
Murakami T, Nakamura H, Monden M. Intrahepatic recurrences of hepatocellula carcinoma after hepatectomy: analysis based on tumor hemodynamics. Arch Surg 2002; 137: 94-99.

2. Abrams P, Marsh JW. Current approach to hepatocellular carcinoma. Surg Clin North Am. 2010; 90(4): 803-816.

3. Mou DC, Cai SL, Peng JR, Wang Y, Chen HS, Pang XW, Leng XS, Chen WF. Evaluation of MAGE-1 and MAGE-3 as tumour-specific markers to detect blood dissemination of hepatocellular carcinoma cells $\mathrm{Br}$ J Cancer. 2002; 86: 110 - 116

4. Wong IH, Leung T, Ho S, Lau WY, Chan M, Johnson PJ. Semiquantitation of circulating hepatocellular carcinoma cells by reverse transcriptase polymerase chain reaction. Br J Cancer. 1997; 76(5): $628-633$

5. Suzuki K, Tsujitani S, Konishi I, Yamaguchi Y, Hirooka Y, Kaibara N. Expression of MAGE genes and survival in patients with hepatocellular carcinoma. Int J Oncol. 1999; 15:1227-1232

6. Baker PA, Salehi A. The MAGE proteins: emerging roles in cell cycle progression, apoptosis, and neurogenetic disease. J. Neurosci. Res. 2002; 67: 705-712

7. Nagao $T$, Higashitsuji $H$, Nonoguchi K, Sakurai T, Dawson S, Mayer RJ, Itoh K, Fujita J. MAGE-A4 interacts with the liver oncoprotein gankyrin and suppresses its tumorigenic activity. J. Biol. 
Chem. 2003; 278 (12): 1066810674.

8. Kariyama $K$, Higashi $T$, Kobayashi Y, Nouso $\mathbf{K}$, Nakatsukasa $H$, Yamano $T$, Ishizaki M, Kaneyoshi T, Toshikuni N, Ohnishi T, Fujiwara K, Nakayama E, Terracciano L, Spagnoli GC and Tsuji T. Expression of MAGE-1 and -3 genes and gene products in human hepatocellular carcinoma. Br J Cancer. 1999; 81(6): 1080-1087

9. Gunther FL, Hofbauer L, Schaefer C, Noppen C, Boni R, Kamarashev J, Nestlé FO, Spagnoli GC and Dummer $R$. MAGE-3 immunoreactivity in formalinfixed paraffin-embedded primary and metastatic melanoma. Am J Pathol. 1997; 151: 1549-1553

10. Chen CH, Huang GT, Lee HS, Yang PM, Yan MD, Chen DS, Sheu JC. High genes frequency in human of expression of MAGE hepatocellular carcinoma Liver 1999; 19: 110-114.

11. Tahara K, Mori M, Sadanaga N, Sakamoto Y, Kitano S, Makuuchi M. Expression of the MAGE gene family in human hepatocellular carcinoma. Cancer 1999; 85:1234-1240.

12. Houghton RL, Dillon DC, Molesh DA, Zehentner BK, Xu J, Jiang J, Schmidt C, Frudakis A, Repasky E, Maltez Filho A, Nolasco M, Badaro R, Zhang $X$, Roche PC, Persing DH, Reed SG. Transcriptional complementarity in breast cancer: application to detection of circulating tumor cells. Mol Diagn. 2001; 6(2):7991.

13. Berois $N$, Varangot $M$, Aizen B, Estrugo R, Zarantonelli L, Fernández $P$, Krygier $G$, Simonet F, Barrios E, Musé I, Osinaga E. Molecular detection of cancer cells in bone marrow and peripheral blood of patients with operable breast cancer. Comparison of CK19, MUC1 and CEA using RT-PCR. Eur J Cancer. 2000; 36(6):717723.

14. Jiang SY, Shyu RY, Huang MF, Tang HS, Young TH, Roffler SR, Chiou YS, Yeh MY. Detection of alphafetoprotein expressing cells in the blood of patients with hepatoma and hepatitis. Br J Cancer 1997; 75: $928-933$.

15. Malek L, Jerome N, Herve $Z$, Abdelmajid S, Corinne V, Giovanna V, Karine P, Monique $\mathbf{T}$, Frederique $\mathrm{C}$, Stanislas $P$, Dominique F, Bernard L, Christian B, Paterlini PB. Liver resection and needle liver biopsy cause hematogeneous dissemination of liver cells. Hepatology 1999; 29: $879-882$.

16. Peck-Radosavljevic M, Pidlich J, Bergmann M, Ferenci $\mathbf{P}$, Seelos C, Wichlas M, Lipinski E, Gnant M, Gangl A, Mühlbacher F. Preoperative TNM-classification is a better prognostic indicator for recurrence of hepatocellular carcinoma after liver transplantation than albumin mRNA in peripheral blood. Liver 
Transplant Oncology Group. J Hepatol. 1998; 28(3):497-503.

17. Lemoine, Le Bricon T, Salvucci M, Azoulay D, Pham P, Raccuia J, Bismuth H, Debuire B. Prospective evaluation of circulating hepatocytes by alphafetoprotein mRNA in humans during liver surgery. Ann Surg. 1997; 226(1): 43-50.

18. Barbu V, Bonnand AM, Hillaire S, Coste T, Chazouilleres O, Gugenheim J, Boucher E, Poupon R, Poupon RE. Circulating albumin messenger RNA in hepatocellular carcinoma: results of a multicenter prospective study. Hepatology. 1997;26(5):1171-5.

19. Yuasa T, Okamoto $K$, Kawakami T, Mishina M, Ogawa O, Okada Y. Expression patterns of cancer testis antigens in testicular germ cell tumors and adjacent testicular tissue. J Urol 2001; 165: 1790-1794.

20. Zhang Y, Li Q, Liu N, Song T, Guo R, Meng L, Hao $\mathrm{X}$. Multimarker Detection of MAGE-1, MAGE-3 and AFP
mRNAs by a Real-time Quantitative PCR Assay: a Possible Predictor of Hematogenous Micrometastasis of Hepatocellular Carcinoma. Chin J Clin Oncol 2008; 5: 93-98

21. Tsuzuraharsa S, Sata M , Iwamoto O, Shichijo S, Kojiro M, Tanikawa $\mathbf{K}$, Itoh $\mathbf{K}$. Detection of MAGE-4 protein in the sera of patients with hepatitisc virus-associated hepatocellular carcinoma and liver cirrhosis. Jpn J Cancer Res 1997; 88: 915-8.

22. Imamura H, Matsuyama $Y$, Tanaka E, Ohkubo T, Hasegawa K, Miyagawa $\mathrm{S}$, Sugawara $\mathbf{Y}$, Minagawa $M$, Takayama T, Kawasaki S, Makuuchi M. Risk factors contributing to early and late phase intrahepatic recurrence of hepatocellular carcinoma after hepatectomy. J Hepatol 2003; 38: 200-207.

23. Yanaga K. Current status of hepatic resection forhepatocellular carcinoma. J Gastroenterol 2004; 39:919-926. 


\section{الملخص العربى}

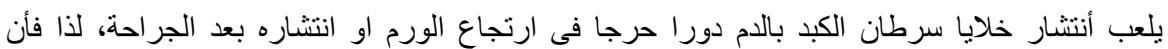

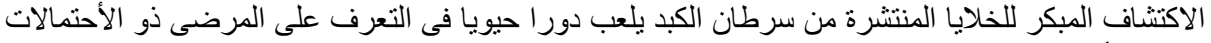

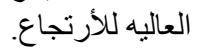

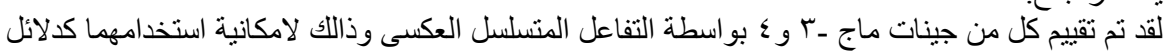

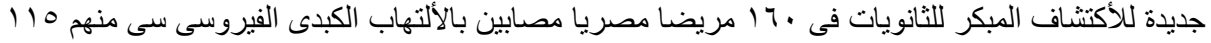
مريضا مصابين بسرطان الكبد الكبات

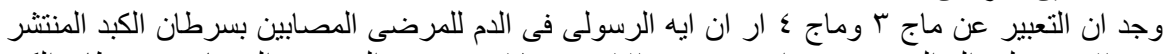

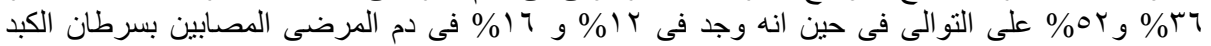

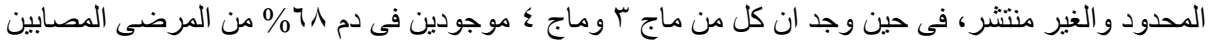

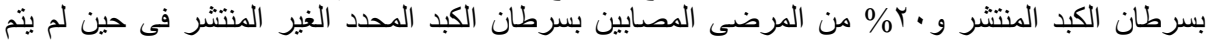

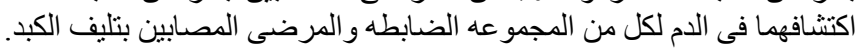

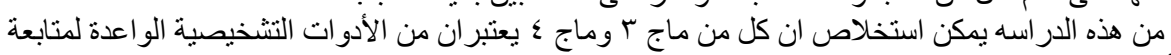
و الأكتثاف المبكر لوجود ثنانويات سرطان الكبد فى اللدم. 